\title{
Estrogens, phytoestrogens and colorectal neoproliferative lesions
}

\author{
Michele Barone - Sabina Tanzi - Katia Lofano - Maria Principia Scavo · \\ Raffaella Guido - Lucia Demarinis - Maria Beatrice Principi · \\ Antongiulio Bucci $\cdot$ Alfredo Di Leo
}

Published online: 1 March 2008

(c) Springer-Verlag 2008

\begin{abstract}
Epidemiological and experimental studies suggest a protective role of estrogens against colorectal cancer. This effect seems to be mediated by their binding to estrogen receptor beta (ER- $\beta$ ), one of the two estrogen receptors with high affinity for these hormones. Very recently, the demonstration of an involvement of ER- $\beta$ in the development of adenomatous polyps of the colon has also been documented, suggesting the use of selective ER- $\beta$ agonists in primary colorectal cancer prevention. Phytoestrogens are plant-derived compounds that structurally and functionally act as estrogen-agonists in mammals. They are characterized by a higher binding affinity to ER- $\beta$ as compared to estrogen receptor alpha $(E R-\alpha)$, the other estrogen receptor subtype. These biological characteristics explain why the administration of phytoestrogens does not produce the classical side effects associated to estrogen administration (cerebro- and cardiovascular accidents, higher incidence of endometrial and breast cancer) and makes these substances ideal candidates for the prevention of colorectal cancer.
\end{abstract}

Keywords Phytoestrogen - Sex steroid hormones · Silymarin $\cdot$ ER- $\beta$ - Adenomatous polyp $\cdot$ Colon cancer

M. Barone $(\bowtie) \cdot S$. Tanzi $\cdot$ K. Lofano ·

M. P. Scavo - R. Guido - L. Demarinis .

M. B. Principi - A. Bucci · A. Di Leo ( $\square)$

Facolta' di Medicina e Chirurgia, Universita' di Bari, Bari, Italy

e-mail: m.barone@gastro.uniba.it

A. Di Leo

e-mail: a.dileo@gastro.uniba.it

\section{Estrogens and colorectal neoproliferative lesions}

In the last 40 years, a reduction of deaths from large bowel carcinoma has been observed in the United States. This reduction was significantly higher in women $(30 \%)$ as compared to men $(7 \%)$. In the same study, a link was observed between oral contraceptive use and a reduction of colorectal cancer, whereas there was a higher than expected frequency of colorectal tumors among nuns (non users) [6]. On the basis of these observations, it has been proposed that the greater reduction in deaths from colorectal cancer (CRC) in women, might be due to the influence of female sex steroid hormones. In order to verify this hypothesis in a randomized controlled study named the "Women's Health Initiative" the development of colorectal neoplasia was evaluated in 32,000 American postmenopausal women: 16,000 women were treated with Hormone Replacement Therapy (HRT) and 16,000 did not receive any therapy.

The data obtained demonstrated a reduction of the colon carcinoma risk by $33 \%$ and of the relative risk of death (0.72) in women taking HRT as compared to controls [61].

In addition, experimental data have demonstrated that in CRC expressing an elevated number of estrogen receptors (ERs) there is a low tissue level of polyamines (polycationic compounds actively involved in cell proliferation and differentiation) [41].

The importance of this finding was later confirmed by the use of polyamine synthesis inhibitors, that showed a high inhibitory effect on tumor development and metastases [41]. In addition, polyamine levels were correlated with the histological grade of the tumor, and were influenced by patient gender and age [62].

Although several experimental studies have confirmed a protective role of estrogens for CRC $[16,18,28,31,50,58$, 
67], few studies have been conducted, and with conflicting results, on the possible protective effect of estrogens against the development of adenomatous polyps in the colon, although it is well known that the development of adenocarcinoma mostly involves polyp formation [69]. Among these studies, the "Polyp Prevention Trial" was performed in order to verify if HRT influences the recurrence of adenomatous polyps. The results obtained demonstrated a significant reduction of the risk of recurrence only for distal adenomas [74]. This reduced risk for recurrence was related to the age of the patients and was observed only in women aged over 62 years, whereas the risk was increased in women under 62 years. However, these data cannot be extended to entire female population since the study was conducted only in women with a previous endoscopic diagnosis of adenomatous polyps.

Other prospective and retrospective epidemiological studies have considered the effect of current and past use of hormones, taking in account the duration of use and the dosage of estrogens taken. One of these studies, a large prospective cohort study named the "Nurses' Health Study", examined whether postmenopausal HRT decreased the risk of distal CRC and adenoma during a 14 year follow-up [21]. They found a decreased risk only for distal adenomas and for large ones among women that were current hormone users; a smaller apparent reduction was noted for past users. However, in this study, the protective effect was not correlated to the duration of HRT and only an estrogen dosage related trend was observed. No association was seen between small adenomas and hormone administration. Finally, the case of a young woman affected by familial adenomatous polyposis, has recently been described, in which a striking reduction of adenomatous polyps was observed after the administration of oral contraceptives [19].

A recent experimental study on the effect of estrogens on colorectal polyp development has demonstrated a protective role of these hormones in $\mathrm{APC}^{\mathrm{Min} /+}$ female mice, that spontaneously develop intestinal adenomas. After ovariectomy, these animals showed an increased (77\%) intestinal adenoma formation, while the successive administration of $17-\beta$-estradiol determined a reduction of intestinal adenomas [71].

\section{Molecular aspects of ERs}

The biological activity of estrogens is mainly mediated by their binding with two specific receptors: estrogen receptor alpha $($ ER- $\alpha)$ and estrogen receptor beta $($ ER- $\beta)$. Both of these estrogen receptors (ERs) belong to the steroid/thyroid hormone receptor superfamily of nuclear receptors, which are actived upon binding of the ligand.
After binding the ligand, the activated ERs are able to interact with cis-regulatory elements of target genes directly by binding to estrogen-response elements (EREs) or indirectly through interaction with another DNA-bound transcription factor, such as activator protein 1 (AP-1) (Fig. 1), thus facilitating the assembly of basal transcription factors into a stable pre-initiation complex followed by increased transcription rates for target mRNAs [55, 63].

Both ERs consist of three main regions: (1) a hypervariable $\mathrm{N}$-terminal, that contributes to the transactivation function, (2) a highly conserved DNA-binding domain, responsible for specific DNA-binding and dimerization and (3) a C-terminal domain, involved in ligand-binding (LBD) and nuclear localization, and ligand-dependent transactivation functions $[43,68]$. ER- $\alpha$ and ER- $\beta$ are produced by different genes located on different chromosomes [15, 46]. In mammals both ER $\alpha$ and ER- $\beta$ have conserved DNAbinding domains $(96 \%)$ but they differ in their LBD showing only $58 \%$ homology [53]. ER- $\alpha$ has two distinct transcriptional activation functions (AF): AF-1 and AF-2. $\mathrm{AF}-1$, located at the N-terminal, is ligand-independent, constitutively active and contributes to the transcriptional activity of the receptor by recruiting co-activator proteins such as GRIP1 and SRC-1 and the histone acetyltransferases (HAT) p300/CBP and pCAF [9, 20]. The AF-2 domain is under the control of ligands in both ER- $\alpha$ and ER- $\beta$.

Variations in the phenotypes of knock-out mice lacking ER- $\alpha$ or ER- $\beta$ suggest that these two proteins have different biological activities [11, 24]. This view was further supported by in vitro and in vivo studies in ER- $\beta$ knock out mice, indicating that ER- $\beta$ is a modulator of ER- $\alpha$ activity

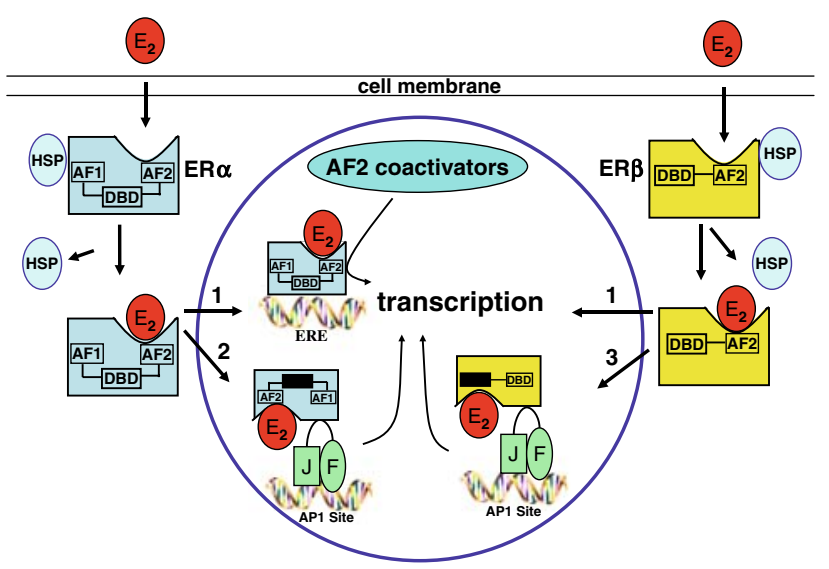

Fig. 1 Estrogen receptors genomic pathway. Estrogens $\left(E_{2}\right)$ enter the cell by diffusion and bind to specific receptor proteins (ERs). Upon estrogen binding, ERs either bind effectively to DNA elements of their target genes or activate other genes through the interaction with AP-1 site. In both cases, ERs activate transcription, protein synthesis and finally several biological effects. $E R E$ estrogen response element, $A P-1$ activator protein 1 
as it is able to reverse the effects of ER- $\alpha$ and to inhibit estradiol $\left(E_{2}\right)$ dependent proliferation $[25,42,55,70]$.

In addition, it is known that ER- $\alpha$ and ER- $\beta$ have a different distribution in the various organs and apparatuses. ER- $\alpha$ is essentially expressed in the breast, bone, cardiovascular tissue, urogenital tract and central nervous system, while ER- $\beta$ is the prevalent form in the gut [49]. Both receptors bind $E_{2}$ but they activate promoters in different ways. Studies on breast and prostate carcinogenesis suggest an opposite role of ER- $\alpha$ and ER- $\beta$ in the proliferation and differentiation of target tissues, a hypothesis described as the ying/yang relationship [40, 49]. In addition, estrogens regulate cellular function also by non-genomic pathways (Fig. 2). In fact, palmitoylation of ERs allows them to localize at the plasma membrane, to associate to caveolin-1 and, upon estrogens stimulation, to activate rapid signals. In the case of ER- $\alpha$, palmitoylation stimulates proliferation, while ER- $\beta$ localization at the plasma membrane and its association with caveolin- 1 activates p38 (a member of the MAPK family), that promotes apoptosis [17].

This finding is confirmed by the presence, in the tumoral tissue, of a reduction of ER- $\beta$ and an increased alpha/beta ratio, that is related to a reduction of apoptosis and an increased rate of proliferation.

\section{ER $\beta$ and CRC}

Although previous studies on the protective role of estrogens against colorectal cancer produced contrasting results, the demonstration that estrogens bind two different types of receptors (that seem to be antagonists) has generated new

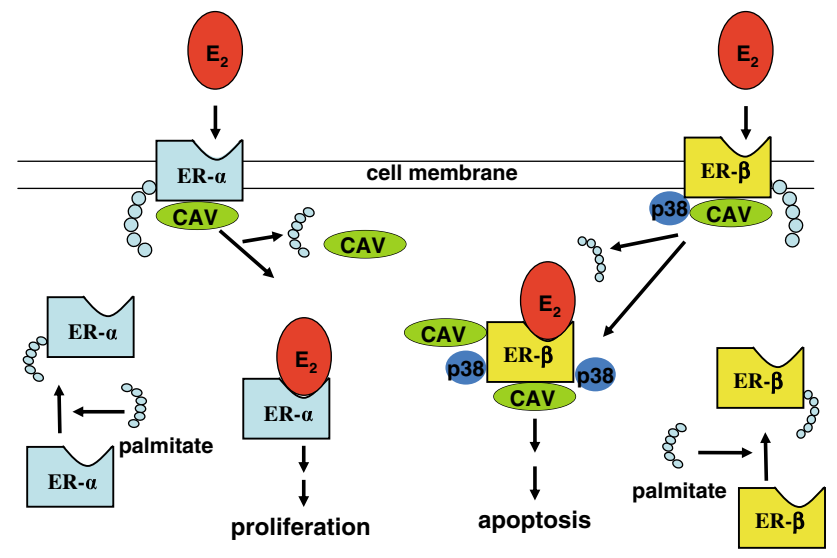

Fig. 2 Estrogen receptors non-genomic pathways. Palmitoylation of cytosolic ERs (ERs + palmitate) allows them to localize at the plasma membrane where they associate with caveolin-1 (CAV). Upon estradiol $\left(\mathrm{E}_{2}\right)$ stimulation, ER- $\alpha$ is de-palmitoylated and dissociated from caveolin-1, stimulating signals of cell proliferation. On the contrary, after binding to ER- $\beta, \mathrm{E}_{2}$ increases the association of the receptorial complex with caveolin-1 and p38 (a member of the MAPK family), in order to promote apoptosis interest in this field of research, promoting studies on the use of selective agonists for ER- $\alpha$ or ER- $\beta$.

A positive aspect related to the introduction of these selective ER agonists is the fact that the use of ER- $\beta$ agonists is not associated to an increased risk of cerebroand cardio-vascular events, and does not implicate a higher risk of endometrial and breast cancer, pathological conditions that are at increased risk during the use of HRT or oral contraceptives [51].

Kostantinoupolous et al. have demonstrated that ER- $\beta$ is highly expressed in normal colonic mucosa in humans while it is significantly reduced in $\mathrm{CRC}$; this reduction is more pronounced in the case of scarcely differentiated tumors.

Since the majority of CRCs are derived from adenomatous polyps (a precancerous condition) we have recently evaluated the expression of ER- $\alpha$ and ER- $\beta$ in the colonic tissue of 25 patients with adenomatous polyps of the colon and in 25 normal subjects [13]. ERs expression was then correlated to proliferation and apoptosis. Our data confirmed that ER- $\beta$ is the prevalent estrogen receptor in normal mucosa and that in adenomatous polyps there is a significant reduction of its expression. In addition, we demonstrated that in the adenomatous tissue the proliferative activity was inversely related to the expression of ER$\beta$. All these data confirmed that sex steroid hormones are involved in CRC development and suggest that ER- $\beta$ could play an important role in the early phase of the carcinogenetic process and hence could be a target in the primary prevention of CRC.

On the basis of these considerations ER- $\beta$ selective agonists could be the ideal candidates in CRC prevention.

\section{Phytoestrogens}

Phytoestrogens are plant-derived compounds (heterocyclic non steroid phenols) that structurally and functionally act as estrogens agonists in mammals [34, 57].

These substances have been widely studied for their potential therapeutic use in the prevention of cardiac disease, menopausal symptoms, osteoporosis, and some carcinomas, since they show some of the protective effects of estrogens in absence of the previously mentioned side effects associated to estrogen administration [35, 65]. This is due to the fact that their binding affinity to ERs is different from estradiol, being high for ER- $\beta$ (even higher than estradiol itself) and low for ER- $\alpha$ [37]. For this reason phytoestrogens can act as estrogen agonists or antagonists according to the type of ER present in the tissue, its expression, and the level of endogenous circulating hormones [22, 60]. This explains why they are considered selective modulators of ERs (SERMs) [10]. 
Several synthetic molecules, that belong to the family of SERMs, are commercially available, including tamoxifen and raloxifene. These two drugs are commonly used in the clinical practice as both estrogen antagonists and agonists. They were initially studied in breast tissue where they demonstrated the ability to reduce tumor cell proliferation. At the same time, they act as estrogen agonists in the bone and cardiovascular system, where they counteract osteoporosis and coronary syndromes. Finally, in the uterus, tamoxifen shows a similar activity to estrogen and for this reason is associated to a higher risk of endometrial carcinoma [56, 59].

As proposed for estrogens, genomic and non-genomic mechanisms have been suggested also for phytoestrogens to explain their biological activities [7].

Genomic pathways are mediated through the ability of phytoestrogens to interact with enzymes and receptors and cross the plasma membrane [4]. In this way, they bind ERs and induce the transcription of estrogen-responsive genes, stimulate cell growth in the breast and modify ER transcription itself [5, 38, 64]. However, some of their effects are not due to interaction with ERs and are therefore denominated non-genomic effects [47]. The latter include: inhibition of tyrosine kinase and DNA topoisomerase, suppression of angiogenesis and antioxidant effects [39]. In addition, it has been suggested that they can reduce the cancer risk in some tissues (breast, prostate, liver and uterus) by lowering the biological activity of the endogenous sex steroid hormones. This effect might be due to their ability to modulate some enzymes involved in the catabolism of these hormones [3, 44].

The bioavailability and the activity of phytoestrogens vary on the basis of several factors, such as their administration route, dosage, metabolism and their interaction with other pharmacological substances. In addition, their biological effect is influenced by the type of target tissue, the number and type of ERs expressed in the tissue, their serum concentration and sex steroid hormone concentration [32, $73,76]$.

\section{Classification of phytoestrogens}

Four classes of phytoestrogens are distinguished, on the basis of their different molecular structure, that obviously implicates different biological activities: isoflavones, lignans, coumestans and lactones [45, 72].

Isoflavones, including genistein and quercitin, are the best known phytoestrogens. They are primarily found in the Fabaceae family, which includes legumes, soy, peanut and clover. Lignans were first identified in plants and later in biological fluids of mammals. These compounds are found in whole grain, seeds, fruits and vegetables but also in beverages such as coffee and tea [1]. The cyclic urinary excretion of these phenolic compounds during the menstrual cycle has led to investigations of their biological role, and to considering them as a new hormone class [2]. Coumestans are less common in the human diet than isoflavones, and are extracted from fodder, clover, legumes and soybean. Lactones are the less represented phytoestrogens in the human diet. Natural phytoestrogens undergo glycosidic binding to carbohydrates to produce complex molecules that are hard for the intestinal tract to absorb. Therefore, after ingestion, the glycosidic binding is broken up by glycosidases, enzymes produced by intestinal microflora. This enzymatic digestion generates "aglycone". This compound is quickly absorbed and it can bind ERs [52].

An experimental study demonstrated that intestinal flora bacteria metabolize phytoestrogens and produce metabolites similar to estrogens, featuring anti cancer properties [27].

Other studies have discussed the putative effects of phytoestrogens in breast, endometrial, liver and prostatic neoplasia [12].

\section{Phytoestrogens and CRC}

Several studies have reported a lowered colorectal cancer risk associated with the consumption of soy foods. However, these epidemiologic findings have not been confirmed. Some of these studies were conducted in Asia and Hawaii and evaluated the association between individual soy foods (the main source of isoflavones) and colorectal cancer risk [21, 26, 29, 54, 71]. Although some of the studies reported a reduced colorectal cancer risk, particularly for non-fermentated soy foods (e.g. tofu), a lack of association between tofu intake and colorectal cancer risk was also reported, and findings in the various studies differed according to the colorectal cancer sub-site, type of soy food, and sex. The only case-control study conducted in North America found that legumes and soy products (analyzed as a single group) were associated with a reduction in colorectal cancer risk; however, tofu alone showed no association [66]. The main limitations of these studies were the assessment of specific soy food intake rather than total phytoestrogen intake. None of these studies were designed to evaluate phytoestrogen intake; so the evidence of an association is indirect. A recent study conducted in Toronto investigated the association between colorectal cancer and lignans commonly present in Western diets. Dietary lignan intake was associated with a significant reduction in colorectal cancer risk as was isoflavone intake. The authors also evaluated interactions between polymorphic genes that encode enzymes possibly involved in the metabolism of phytoestrogens (CYPs, catechol $O$-methyl transferase, GSTs, and UGTs) and found no 
significant modification effect with respect to phytoestrogen intake [12].

The finding that phytoestrogen intake may reduce colorectal cancer risk is important because dietary intake is potentially easily modifiable [12].

A recent study demonstrated that the administration of a diet enriched with the phytoestrogen cumestrol in ovariectomized $\mathrm{APC}^{\mathrm{Min} /+}$ female mice induced a reduction of the number of polyps and an increase of enterocyte migration compared to control animals. Cumestrol was chosen since it is a potent ER- $\beta$ agonist, with an affinity 200 fold higher than $E_{2}[30]$.

\section{Phytoestrogens and polyps}

Very few epidemiologic studies on the relation between phytoestrogens and the risk of colorectal adenomas have been conducted. One of these is a Dutch case-control study conducted on the role of lignans [8]. Dietary lignans are converted by the intestinal microflora into enterolignans [enterodiol (END) and enterolactone (ENL)] that may be protective against cardiovascular diseases and cancer. A substantial reduction in colorectal adenoma risk was observed among subjects with high plasma concentrations of enterolignans, in particular END. However, this association was observed in incident cases only, not in prevalent cases. This may be due to an earlier first diagnosis of prevalent adenomas than of incident cases [36].

The use of enterolignans as biomarkers of dietary lignans intake was studied, and a modest association between lignan intake and plasma END and ENL was found. The plasma concentrations of both END and ENL were associated with the intake of dietary fiber and vegetable protein but not of other macronutrients. The relation was modulated by age and previous use of antibiotics, whereas for ENL, it was modulated by weight, current smoking habit, and bowel movement frequency [48].

\section{Silymarin}

Silymarin, initially extracted from Silybum marianum, is a mixture of four flavolignans (silybinin, isosilybinin, silydianin and silychristin) and the isoflavone taxifolin. It is already used in the treatment of alcoholic liver disease and as an anti fibrotic agent [71].

Seidlova-Wuttke et al. [75] have compared the effect of silymarin and $\mathrm{E}_{2}$ in ovariectomized female mice, demonstrating that $\mathrm{E}_{2}$ acts on the pituitary gland, determining a reduction of luteinizing hormone (LH) serum levels, and on the liver, determining a reduction of total cholesterol serum levels, and shows uterotrophic and anti osteoporotic effects, whereas silymarin does not show any of these effects. Since all the above-mentioned biological activities are ER- $\alpha$ mediated, these authors have suggested that silymarin could be an ER- $\beta$ selective agonist. They confirmed this hypothesis by in vitro experiments demonstrating a selective binding of silymarin to ER- $\beta$ and no binding to ER- $\alpha$. In another study, conducted by Khono et al. [33], a silymarin-enriched diet significantly reduced azoxymethane-induced intestinal carcinogenesis in male mice. This effect was dose-dependent and determined a reduction of the number of cryptic adenomas, that are known to anticipate the development of colic adenocarcinoma. This effect was, in part, due to a significant reduction of cell proliferation, an increase of apoptosis, and a reduction in carcinomatous tissues of $\beta$-glucuronidase activity, $\mathrm{PGE}_{2}$ levels and polyamine content [33].

On the basis of the data in literature, we tested the effect of a $0.2 \%$ silymarin-enriched diet on tumor development in $\mathrm{APC}^{\mathrm{Min} /+}$ male mice. Control animals received a similar diet to the one given to silymarin treated animals (5K20 diet), i.e. a fat-enriched since it accelerates polyps formation in $\mathrm{APC}^{\mathrm{Min} /+}$ mice.

In our experimental conditions, silymarin administration determined relevant biological effects on polyp formation and development [14]. Briefly, in silymarin-treated animals the number and the volume of polyps were significantly diminished and showed a lower grade of dysplasia compared to the control group. In addition, the expression of ER mRNA and protein levels was significantly higher in the intestinal mucosa of silymarin-treated animals that showed also an increased, cell migration together with a reduction of proliferation compared to control group. Interestingly, we have recently demonstrated also an increased apoptotic activity in sylimarin treated animals as compared to controls $(16.27 \pm 0.49$ vs. $10.7 \pm 4.2$, respectively, $P<0.02)$. All these results suggest a possible role of silymarin in the primary prevention of intestinal tumors.

\section{References}

1. Adlercreutz H, Fotsis T, Heikkinen R, Dwyer JT, Goldin BR, Gorbach SL, Lawson AM, Setchell KD (1981) Diet and urinary excretion of lignans in female subjects. Med Biol 59(4):259-261

2. Adlercreutz H, Höckerstedt K, Bannwart C, Bloigu S, Hämäläinen E, Fotsis T, Ollus A (1987) Effect of dietary components, including lignans and phytoestrogens, on enterohepatic circulation and liver metabolism of estrogens and on sex hormone binding globulin (SHBG). J Steroid Biochem 27(4-6):1135-1344 (Review)

3. Adlercreutz H (1998a) Epidemiology of phytoestrogens. Baillieres Clin Endocrinol Metab 12(1):605-623

4. Adlercreutz H (1998b) Evolution, nutrition intestinal microflora and prevention cancer: a hypotesis. Proc Soc Exp Biol Med 217(3):241-246 
5. Adlercreutz H, Mazur W, Stumpf K et al (2000) Food containing phytoestrogens, and breast cancer. Biofactors 12(1-4):89-93

6. American Cancer Society (1995) Cancer fact figures. American Cancer Society, Atlanta

7. Anderson JJB, Anthony M, Messina M, Garner SC (1999) Effect of phytoestrogens on tissues. Nutr Res Rev 12(3):75-116

8. Axelson M, Sjövall J, Gustafsson BE, Setchell KD (1982) Origin of lignans in mammals and identification of a precursor from plants. Nature 298(5875):659-660

9. Bevan C, Parker M (1999) The role of coactivators in steroid hormone action. Exp Cell Res 253(2):349-356

10. Brzezinski A, Debi A (1999) Phytoestrogens: the natural selection estrogen receptors modulators? Eur J Obstet Gynecol Reprod Biol 87(2):47-51

11. Couse JF, Curtis Hewitt S, Korach KS (2000) Receptor null mice reveal contrasting roles for estrogen receptor alpha and beta in reproductive tissues. J Steroid Biochem Mol Biol 74(5):287-296

12. Cotterchio M, Boucher BA, Manno M, Gallinger S, Okey A, Harper P (2006) Dietary phytoestrogen intake is associated with reduced colorectal cancer risk. J Nutr 136(12):3046-3053 (Author manuscript)

13. Di Leo A, Barone M, Maiorano E, Tanzi S, Piscitelli D, Marangi S, Lofano K, Ierardi E, Francavilla A (2008) ER-beta expression in large bowel adenomas: implications in colon carcinogenesis. Dig Liv Dis (in press)

14. Di Leo A, Maiorano M, Margiotta M, Tanzi S, Guido R, Demarinis L, Scavo MP, Francioso F, Francavilla A (2007) Effect of an estrogen receptor beta selective agonist (Sylimarin) upon intestinal adenoma development in a mouse model of adenomatous polyposis coli (APC). Gastroenterology 132(4) suppl 2:A631

15. Enmark E, Pelto-Huikko M, Grandien K, Lagercrantz S, Lagercrantz J, Fried G,Nordenskjold M, Gustafsson JA (1997) Human estrogen receptor beta-gene structure, chromosomal localization, and expression pattern. J Clin Endocrinol Metab 82(12):4258-4265

16. Fernandez E, La Vecchia C, Braga C, Talamini R, Negri E, Parazzini $\mathrm{F}$ et al (1998) Hormone replacement therapy and risk of colon and rectal cancer. Cancer Epidemiol Biomarkers Prev 7(4):329-333

17. Galluzzo P, Caiazza F, Moreno S, Marino M (2007) Role of ERbeta palmitoylation in the inhibition of human colon cancer cell proliferation. Endocr Relat Cancer 14(1):153-167

18. Gerhardsson de Verdier M, London S (1992) Reproductive factors, exogenous female hormones, and colorectal cancer by subsite. Cancer Causes Control 3(4):355-360

19. Giardiello FM, Hylind LM, Trimbath JD, Stanley R, Hamilton $\mathrm{KE}$ et al (2005) Oral contraceptives and polyp regression in familial adenomatous polyposis. Am Gastroenterol Assoc 128(4):1077-1080

20. Glass CK, Rosenfeld MG (2000) The coregulator exchange in transcriptional functions of nuclear receptors. Genes Dev 14(2):121-141

21. Grodstein F, Martinez ME, Platz A, Giovannucci E, Colditz A, Kautzky M, Fuchs C, Stampfer MJ (1998) Postmenopausal hormone use and risk for colorectal cancer and adenoma. Ann Intern Med 128(9):705-712

22. Gruber CJ, Tschugguel W, Schneeberger C, Huber JC (2002) Production and actions of phytoestrogens. N Engl J Med 346(5):340-352

23. Gustafsson JA, Pettersson K, Delaunay F (2000) Estrogen receptor beta acts as a dominant regulator of estrogen signaling. Oncogene 19(1):4970-4978

24. Gustafsson JA (2003) What pharmacologists can learn from recent advances in estrogen signalling. Trends Pharmacol Sci 24(9):479-485
25. Hall JM, McDonnell DP (1999) The estrogen receptor beta-isoform (ERbeta) of the human estrogen receptor modulates ERalpha transcriptional activity and is a key regulator of the cellular response to estrogens and antiestrogens. Endocrinology 140(12):5566-5578

26. Hoshiyama Y, Sekine T, Sasaba T (1993) A case-control study of colorectal cancer and its relation to diet, cigarettes, and alcohol consumption in Saitama Prefecture, Japan. Tohoku J Exp Med 171(2): $153-165$

27. Hur HG, Lay JO Jr, Beger RD, Freeman JP, Rafii F (2000) Isolation of human intestinal bacteria metabolizing the natural isoflavone glycosides daidzin and genistin. Arch Microbiol 174(6):422-428

28. Jacobs EJ, White E, Weiss NS (1994) Exogenous hormones, reproductive history, and colon cancer (Seattle, Washington, USA). Cancer Causes Control 5(4):359-366

29. Jacobson JS, Neugut AI, Garbowsky GC, Ahsan H, Waye JD, Treat MR et al (1996) Hormone replacement therapy is associated with lower risk of adenomatous polyps of the large bowel: the Minnesota cancer prevention research unit case control study. Cancer Epidemiol Biomarkers Prev 5(10):779-784

30. Javid HS, Moran AE, Carothers AM et al (2005) Modulation of tumor $\mathrm{f}$ ormation and intestinal cell migration by estrogens in the Apc Min/+ mouse model of colorectal cancer. Carcinogenesis 26(3):587-595

31. Kampman E, Potter JD, Slattery ML, Caan BJ, Edwards S (1997) Hormone replacement therapy, reproductive history, and colon cancer: a multicenter, case-control study in the United States. Cancer Causes Control 8(2):146-158

32. Kelly GE, Joannou GE, Reeder AY, Nelson C, Waring MA (1995) The variable metabolic response to dietary isoflavones in humans. Proc Soc Exp Biol Med 208(8):40-43

33. Khono H, Tanaka T, Kawabata K, Hirose Y, Sugie S, Tsuda H, Mori H (2002) Silymarin, a naturally occurring polyphenolic antioxidant flavonoid, inhibits azoxymethane-induced colon carcinogenesis in male F344 rats. Int J Cancer 101(5):461-468

34. Knight DC, Eden JA (1996) A review of the clinical effects of phytoestrogens. Obstet Gynecol 87(5 Pt 2):897-904

35. Kronenberg F, Fugh-Berman A (2002) Complementary and alternative medicine for menopausal symptoms. A review of randomized, controlled trials. Ann Intern Med 137(7):805-813

36. Kuijsten A, Arts ICW, Holmann PCH, van't Veer P, Kampman E (2006) Plasma enterolignans are associated with lower colorectal adenoma risk. Cancer Epidemiol Biomarkers Prev 15(6):11321136

37. Kuiper GGJM, Lemmen JG, Carlsson B et al (1996) Interaction of estrogenic chemicals and phytoestrogens with estrogen receptor beta. Endocrinology 139(10):4252-4263

38. Kurzer MS, Xu X (1997) Dietary phytoestrogens. Annu Rev Nutr 17:353-381

39. Kurzer MS (2002) Hormonal effects of soy in premenopausal women and men. J Nutr 132(3):570s-573s

40. Lindberg MK, Movérare S, Skrtic S, Gao H, Dahlman-Wright K, Gustafsson JA, Ohlsson C (2003) Estrogen receptor (ER)-beta reduces ERalpha-regulated gene transcription, supporting a "ying yang" relationship between ERalpha and ERbeta in mice. Mol Endocrinol 17(2):203-208

41. Linsalata M, Russo F, Cavallini A, Berloco P, Di Leo A (1993) Polyamines, diamine oxidase, and ornithine decarboxylase activity in colorectal cancer and in normal surrounding mucosa. Dis Colon Rectum 36(7):662-667

42. Liu MM, Albanese C, Anderson CM, Hilty K, Webb P, Uht RM, Price RH Jr, Pestell RG, Kushner PJ (2002) Opposing action of estrogen receptors alpha and beta on cyclin D1 gene expression. J Biol Chem 277(27):24353-24360 
43. Lundbäck T, Cairns C, Gustafsson JA, Carlstedt-Duke J, Härd T (1993) Thermodynamics of the glucocorticoid receptor-DNA interaction: binding of wild-type GR DBD to different response elements. Biochemistry 32(19):5074-5082

44. Manno M, Cotterchio M, Boucher B, Gallinger S, Okey A, Harper P (2006) Dietary phytoestrogen intake is associated with reduced colorectal cancer risk. J Nutr 136(12):3046-3053

45. Matsuda H, Shimoda H, Morikawa T, Yoshikawa M (2001) Phytoestrogens from the roots of Polygonum cuspidatum:structure requirement of hydroxyanthraquinones for estrogenic activity. Bioorg Mol Chem Lett 11(14):1839-1842

46. Menasce LP, White GR, Harrison CJ, Boyle JM (1993) Localization of the estrogen receptor locus (ESR) to chromosome $6 \mathrm{q} 25.1$ by FISH and a simple post-FISH banding technique. Genomics 17(1):263-265

47. Messina MJ, Loprizi CL (2001) Soy for breast cancer survivors: a critical review of the literature. J Nutr 131(11 Suppl):3095s$3108 \mathrm{~s}$

48. Milder IE, Kuijsten A, Arts IC, Feskens EJ, Kampman E, Hollman PC, Van 't Veer P (2007) Relation between plasma enterodiol and enterolactone and dietary intake of lignans in a Dutch endoscopy-based population. J Nutr 137(5):1266-1271

49. Nelson LR, Bulun SE (2001) Estrogen production and action. J Am Acad Dermatol 45(1):S116-S124

50. Newcomb PA, Storer BE (1995) Postmenopausal hormone use and risk of large-bowel cancer. J Natl Cancer Inst 87(6):10671071

51. Newcomb PA, Storer BE (2002) Postmenopausal hormone replacement therapy: scientific review. J Am Med Assoc 110(11):219-227

52. Otieno DO, Shah NP (2007) Endogenous beta-glucosidase and beta-galactosidase activities from selected probiotic microorganisms and their role in isoflavone biotransformation in soymilk. J Appl Microbiol 103(4):910-917

53. Pace P, Taylor J, Suntharalingam S, Coombes RC, Ali S (1997) Human estrogen receptor beta binds DNA in a manner similar to and dimerizes with estrogen receptor alpha. J Biol Chem 272(9):25832-25838

54. Peipins A, Newman B, Sandler RS (1997) Use of exogenous hormones and risk of colorectal adenomas. Cancer Epidemiol Biomarkers Prev 6(4):671-675

55. Pettersson K, Delaunay F, Gustafsson JA (2000) Estrogen receptor beta acts as a dominant regulator of estrogen signaling. Oncogene 19(8):4970-4978

56. Poulet FM, Roessler ML, Vancutsem PM (1997) Initial uterine alteration caused by developmental exposure to tamoxifen. Reprod Toxicol 11(1):815-822

57. Price KR, Fenwick GR (1985) Naturally occurring oestrogens in foods-a review. Food Addit Contam 2(2):73-106

58. Prihartono N, Palmer JR, Louik C, Shapiro S, Rosenberg L (2000) A case-control study of use of postmenopausal female hormone supplements in relation to the risk of large bowel cancer. Cancer Epidemiol Biomarkers Prev 9(4):443-447

59. Pukkala E, Kyyronen P, Sankila R, Holli K (2002) Tamoxifen and toremifene treatment of breast cancer and risk of subsequent endometrial cancer: a population based case control study. Int $\mathbf{J}$ Cancer 100(3):3337-3341

60. Riggs BL, Hartmann LC (2003) Selective estrogens receptor modulators-mechanisms of action and application to clinical practice. N Engl J Med 348(1):618-629
61. Rossouw JE, Anderson GL, Prentice RL, LaCroix AZ, Kooperberg C, Stephanick ML, Jackson RD, Beresford SA, Howard BV, Johnson KC, Kotchen JM, Ockene J (2002) Risk and benefit estrogen plus progestin in health postmenopausal women: principals results from the Women's Health initiative randomized controlled trial. JAMA 288(3):321-333

62. Russo F, Linsalata M, Messa C, Cavallini A, Notarnicola M, Guerra V, Lantone G, Lacatena M, Di Leo A (1992) Polyamines and estrogen-receptor concentrations in human colorectal carcinomas. Ital J Gastroenterol 24(1):8-12

63. Safe S (2001) Transcriptional activation of genes by 17 betaestradiol through estrogen receptor-Sp1 interactions. Vitam Horm 62:231-252

64. Santti R, Makela S, Strauss L, Korkman J, Kostian ML (1998) Phytoestrogens: potential endocrine disruptors in males. Toxicol Ind Health 14(1-2):223-237

65. Setchell KD (1998) Phytoestrogens: the biochemistry, physiology and implications for human health of soy isoflavones. Am J Clin Nutr 68(6 Suppl):1333s-1146s

66. Theodoratou E, Kyle J, Cetnarskyj R, Farrington SM, Tenesa A, Barnetson R, Porteous M, Dunlop M, Campbell H (2007) Dietary flavonoids and the risk of colorectal cancer. Cancer Epidemiol Biomarkers Prev 16(4):684-693

67. Troisi R, Schairer C, Chow WH, Schatzkin A, Brinton LA, Fraumeni JF Jr (1997) A prospective study of menopausal hormones and risk of colorectal cancer (United States). Cancer Causes Control 8(2):130-138

68. Tsai MJ, O’Malley BW (1994) Molecular mechanisms of action of steroid/thyroid receptor superfamily members. Annu Rev Biochem 63:451-486

69. Vogelstein B, Fearon ER, Hamilton SR, Kern SE, Preisinger AC, Leppert $\mathrm{M}$ et al (1988) Genetic alterations during colorectaltumor development. N Engl J Med 319:525-532

70. Weihua Z, Saji S, Makinen S, Cheng G, Jensen EV, Warner M, Gustafsson JA (2000) Estrogen receptor (ER) beta, a modulator of ERalpha in the uterus. Proc Natl Acad Sci USA 97(11):59365941

71. Weyant MJ, Carothers AM, Mahmoud NN et al (2001) Reciprocal expression of ERalpha and $\mathrm{ERb}$ is associated with estrogen-mediated modulation of intestinal tumorigenesis. Cancer Res 6(1):2547-2551

72. Whitten PL, Naftolin F (1998) Reproductive actions of phytoestrogens. Baillieres Clin Endocrinol Metab 12(4):667-690

73. Wiseman H (1999) The bioavailability of non-nutrient plants factors: dietary flavonoids and phytoestrogens. Proc Nutr Soc 58(1):139-146

74. Woodson K, Lanza E, Tangrea JA, Albert PS, Slattery M, Pinsky J, Caan B, Paskett E, Iber F, Kikendall JW, Lance P, Shike M, Weissfeld J, Schatzkin A (2001) Hormone replacement therapy and colorectal adenoma recurrence among women in the polyp prevention trial. Report J Natl Cancer Inst 93(23):1799-805

75. Wuttke-Seidlova D, Becker T, Cristoffel V, Jarry H, Wuttke W (2003) Silymarin is a selective estrogen receptor beta (ER beta) agonist and has estrogenic effects in the metaphysis of the femur but no antiestrogenic effects in the uterus of ovariectomized rats. J Steroid Biochem Mol Biol 86(1):179-188

76. Xu X, Harris KS, Wang HJ, Murphy PA, Hendrich S (1995) Bioavailability of soybean isoflavones depends upon gut microflora in women. J Nutr 125(9):2307-2315 